\title{
VERSIERINGSKUNST DER BOSCHNEGERS
}

\author{
L. C. van Panhuys, De Nigritarum Syl- \\ vestrium arte ornandi (Specimina quaedam ex \\ Guyana Neerlandica illustrantur). Quelques \\ ornements des nègres des bois de la Guyane \\ néerlandaise.
}

Onder bovengenoemden dubbelen titel is nu eerst (October 1929) een overdruk verschenen van een opstel in de Atti del XXII Congresso internazionale degli Americanisti (Roma, 21-30 settembre 1926). Aangezien genoemde $A t t i$, naar 't schijnt, nog lang niet onder de oogen van alle congresleden zijn gekomen, kan het zijn nut hebben hier de aandacht te vestigen op deze jongste bijdrage tot de kennis der Boschnegers van Jhr. van Panhuys. Zijn eerste geschrift over ornamentiek (der Indianen van Guyana) dagteekent van 1898 (Int. Arch. f. Ethn., Bd. XI), welke „proeve” in den loop der jaren door tal van bijdragen, voornamelijk aangaande Boschnegers, werd gevolgd. De eerste aanleiding daartoe ligt in een verblijf van eenige jaren in Suriname, vooral te Albina aan de Marowijne rivier, waar de heer van Panhuys destijds als ambtenaar geplaatst was. De aldaar verzamelde gegevens zijn niet gering en betreffen bij voorkeur ornamentiek, tatoueeren, muziek en bijgeloof der Boschnegers.

De studie der versieringskunst, niet slechts bij primitieve, maar ook bij halfbeschaafde volken, overal ter wereld, is een der ingewikkeldste onderwerpen der ethnologie. Toen de hr. v. P. mij, destijds conservator aan het Museum te La Plata, in 1896, op raad van wijlen Serrurier, mijn meening en voorlichting verzocht, verkeerde de kennis der exotische ornamentiek eigenlijk nog in haar kindsheid; van gemotiveerde uitlegging en vergelijkende studie was toen nauwelijks questie. Sommige geleerden spraken zelfs van ",grillen”, „Spielereien”, terwijl men nu weet, dat de natuurmensch bij zijn ornamentiek, en trouwens in 't algemeen niet, door grillen geleid wordt. Integendeel; hij gaat te werk volgens zekere vaste beginselen, die diep wortelen in een religieus-mythischen bodem. Zij alle hebben een reden van bestaan. De lichaams- 
versiering, de ornamentiek der ergologica, rotsschilderingen en -teekeningen zijn oorspronkelijk alle redegevend. Somtijds ligt de oorsprong zóó ver in het verleden, dat de hedendaagsche schilderteekenaar, houtsnijder en wever of weefster lang niet altijd meer weet, wàt hij of zij eigenlijk afbeeldt. Niet altijd, maar veelal nog wel. En zoolang de Europeesch-Amerikaansche „,beschaving” haar alles ontaardenden en verderfelijken invloed op de exotische kunst en kunstnijverheid niet uitoefent, schijnt het alsof deze zeer weinig veranderlijk is. Dat er echter hier en daar wederzijdsche acculturatie, van den eenen volksstam op den anderen, valt waar te nemen, is natuurlijk. Dit betreft niet alleen de versieringskunst, maar ook vaak religieus-mythologische voorstellingen, dansen, spelen enz. Voor Zuid-Amerika alléén denke men slechts aan hetgeen Lindblom ${ }^{1}$ ) en Erland Nordenskiöld ${ }^{2}$ ) hebben aangetoond.

Tot de pioniers der studie van exotische ornamentiek behooren de Oostenrijksche gebroeders Hein; v. P. noemt slechts één hunner, Wilhelm H. Sedert dien tijd - zij schreven in 't begin der 90er jaren - is die studie meer algemeen geworden, vooral betreffende Amerikaansche Indianen en Zuidzee-eilanders. Ik noem hier slechts de welbekende namen van Hjalmar Stolpe, Boas en Karl von den Steinen; ook anderen vindt men in de literatuuropgaaf bij v. Panhuys vermeld.

De Boschnegers hebben, dank zij hun afgezonderde woonplaatsen, tot nog toe zeer weinig den invloed der blanken ondervonden. Van daar dat v. P. een groot aantal teekeningen der Boschnegerornamentiek kon vervaardigen en de beteekenis van vele versieringen nog kon te weten komen. De onderhavige mededeeling op het Congres te Rome is slechts een gedeelte van de door Schr. verzamelde gegevens, maar staat in nauw verband met een aantal vroeger verschenen bijdragen over hetzelfde onderwerp. Zoo werden o.a. de door de Gonini- en Tapanahoni-expedities medegebrachte afdrukken van ornamenten door v. P. beschreven.

Door 36 afbeeldingen, naar teekeningen en afdrukken, wordt deze nieuwe bijdrage aanschouwelijk gemaakt. $Z_{i j}$ hebben betrekking op huisversieringen, ornamentiek van korjalen, parels, zitbankjes en kammen, alles houtsnijwerk; dan van borduurwerk op een paar weefsels („pantjes”) benevens tatoueeringen. Het wil mij voorkomen, dat het Schr. vaak gelukt is de beteekenis der

1) Afrikanische Relikte und Indianische Entlehnungen in der Kultur der Buschneger Surinams.

2) Comparative Ethnographical Studies, passim. 
versieringen te weten te komen. In sommige gevallen evenwel, wat hij-zelf trouwens toegeeft, is de uitlegging twijfelachtig, in enkele gevallen m. i. onjuist of minstens onwaarschijnlijk. Primitieven, hetzij Negers, Indianen, Soembaneezen, Berbers en hoe zij verder mogen heeten, zijn, ik weet het uit persoonlijke ervaring, niet juist toeschietelijk of mededeelzaam, wanneer men hen ondervraagt. Gewoonlijk blijven zij uit achterdocht en onwil het juiste antwoord schuldig. Soms is er moedwillige misleiding in het spel of wel onwetendheid. De betrouwbaarheid der antwoorden hangt natuurlijk zeer veel af, of de ondervrager vertrouwd wordt en als vriend beschouwd en dan ook of hij voldoende de taal verstaat en spreekt. Bij v. P. nu waren die voorwaarden aanwezig, zoodat men aan de door hem gegeven uitleggingen een groote mate van waarschijnlijkheid kan toekennen. Dit neemt echter niet weg, dat bij dergelijke onderzoekingen, waar en door wien ook, onvermijdelijke Fehlerquellen de waarheid somtijds vertroebelen.

De hier behandelde Quelques ornements maken over 't geheel uit een aesthetisch oogpunt een gunstigen indruk; zuiver ethnographisch bezien, van Afrikaansch Negerwerk. Een vergelijking met versieringskunst uit West-Afrika bevestigt dien indruk. En bij het zoeken naar oer-Afrikaansche parallellen kan men de beteekenis der Surinaamsche Negerornamentiek controleeren. Hier en daar, maar voornamelijk op p. 236 en 239-241, wijst Schr. op eenige overeenkomsten, ook van elders. De meest voorkomende motieven der Boschnegerornamentiek zijn de mensch en zijn genitalia, de slang en vogels. Fig. 1 en 2 zijn fraaie staaltjes van hutversiering, vooral 2, waar de deur en deurposten rijk versierd zijn. Het valt echter den oningewijde even moeilijk op beide figuren de „menschenhoofden” te vinden, als de „liggende vrouw” op fig. 2. De vervaardiger der ornamenten van fig. 3 (een deur) en van fig. 4 (een korjaal) waren blijkbaar grappenmakers. Een met v. P. bevriende Saramacca Boschneger legde hem namelijk één der deurversieringen uit als zijnde ,een blanke vrouw met een apenkop". En de versierder van de korjaal, ditmaal aan de Marowijne, gaf zijn indruk van de Europeesche vrouw in het snijwerk terug door haar een driehoekig hoofd (= slangenkop) te geven en vlak bij haar een papegaaientong. ${ }^{1}$ ).

1) Hier vraagt v. P. zich af: ,est-ce une impolitesse de la part des nègres des bois envers le beau sexe?" Vermoedelijk wel. De meeste Europeanen vergissen zich zeer met aan te nemen, dat Negers, Indianen en Oosterlingen hen per se mooi vinden. Het tegendeel is eerder waar. Ik heb van die "appreciatie", ook in Suriname, vermakelijke staaltjes gehoord en gezien 
Een merkwaardig staaltje van „versieringskunst” gaf een Saramaccavrouw. Zij vertelde aan v. P. wat zij alzoo in bonte kleuren op den rand van een "pantje” had geborduurd: „een apenstaart, een anker, een omgekeerde korjaal, een hamer, een brief van het Gouvernement met een groot lakzegel er op, een vogel, een Annamitisch juk, een papegaaientong, een copuleerend menschenpaar en weder een apenstaart." Hier zien we dus reeds een ontaarding der exotische versieringskunst, zooals de schilderreiziger W. O. J. Nieuwenkamp die nog veel ergerlijker op Soemba heeft waargenomen ${ }^{2}$ ). (Vergel. het op p. 241 door v. P. gezegde).

Fig. 8 geeft een sterk gestyliseerde ${ }^{2}$ ) menschfiguur zonder hoofd te zien. Tusschen de beenen, maar van het lichaam af, ziet men een cirkel en een driehoek, die door een verticale streep verbonden zijn. De eerste zou den testikel, de driehoek (of pijl) den penis voorstellen. Dit laatste is mogelijk, maar m. i. niet zeker, aangezien primitieven somtijds de regio pubica der vrouw als een driehoek afbeelden. Zeer veel duidelijker dan de meeste menschfiguren en aan geen twijfel onderhevig zijn de afbeeldingen van

die, hoewel niet juist vleiend, toch dikwijls raak waren. Vooral het belachelijke in den blanke wordt spoedig opgemerkt en soms in onbeholpen caricatuurteekeningen, b.v. in Japan, treffend juist weergegeven. Waar evenwel bij Europeanen van beide seksen volgens onze begrippen werkelijk lichamelijke schoonheid voorkomt, wordt die gewoonlijk wel erkend, niet altijd onmiddellijk, maar geleidelijk.

1) Van de voorheen zoo mooie, in-artistieke weefsels zegt hij o. a. dat die door moderne vodden zijn vervangen: geïmporteerde garens en anilinekleuren. „Ook de oude motieven, mensch- en dierfiguren en doodskoppenboom, worden meer en meer verdrongen door patronen ontleend aan etiketten op luciferdoosjes en inmaakblikjes, aan onze munten en aan plaatjes uit tijdschriften. En zoo ziet men tegenwoordig doeken met steigerende leeuwen om het Nederlandsche wapen, met wapperende vlaggen, met fietsen en stoomschepen en wat niet al niet meer." Verder zegt N. dat op Java Bali en overal in onze Oost de inlandsche kunst snel en onherroepelijk te gronde gaat. (Nederlandsch-Indië, Oud en Nieuw, 7e jaarg. 1923, p. 307308).

2) Ik vraag verlof hier een critische, maar eenigszins schoolmeesterachtige aanmerking te maken.

Zeer dikwijls schrijft men in 't Hollandsch bij de versieringskunst van gestyleerde plant- en diervormen en dergelijke. Dit is verkeerd en moet zijn gestyliseerd. Immers, styliseeren is door ons aan 't Fransche styliser ontleend en wordt bij de ornamentbeschrijving gebezigd, styleeren (Fr. styler) daarentegen nooit, tenzij verkeerdelijk. Men spreekt van une plante stylisée, nimmer stylée; daarentegen van un domestique stylé en nooit stylisé. Er was een tijd - heel lang geleden - dat ik aan de Haagsche TeekenAkademie lessen in de geschiedenis van het ornament volgde. Welnu, onze leeraar, die 't goed wist, sprak steeds van styliseeren en gestyliseerd. 
slangen en vogels omdat zij veel minder of niet gestyliseerd zijn (b.v. fig. 28, 29 30/34, 36). Andere versieringen daarentegen zijn ware puzzles, niet zelden voor twee- of drieërlei uitlegging vatbaar. Ik noem b.v. het „anker” op fig. 9 en 17 (vergel. p. 235 van Quelques ornements); de pijl $=$ penis; het leguanenoog $=C y$ praea-schelp = vulva, de kéké (disques à filer); de tjatjali (bobines); de „dondersteenen" en de apoutou.

Evenals de figuren op het houtsnijwerk der Boschnegers hebben hun (litteeken-)tatoueeringen een beteekenis. $\mathrm{Zij}$ hebben dit gemeen met alle volken die zich onder welken vorm ook tatoueeren of beschilderen. Ook daarbij is geen questie van "grillen". Schr. geeft drie voorbeelden (fig. 25, 26 en 27) van Boschnegertatoueeringen bij verschillende personen en geeft er de verklaring van.

Ik kan op een uitvoeriger bespreking dezer Specimina niet ingaan. Niettegenstaande een zekere onvolledigheid dezer bijdrage, doet zij nogmaals het groote belang der studie van de ornamentiek voor de ethno-psychologie uitkomen.

Ten slotte een woord over de drie hoofdresultaten, waartoe v. Panhuys komt. Ik geef ze hier zeer in 't kort samengevat weder, daar zij, hoewel met andere woorden, eigenlijk vrij wel op hetzelfde neerkomen. Bovendien spreken die uitkomsten als van zelf.

De kennis van enkele bepaalde ornamenten leidt tot de verklaring van vele andere, vooral wanneer men vergelijkend te werk gaat bij het bestudeeren der versieringskunst van andere primitieven, ook de vóórhistorischen. Het is ook van belang die onderzoekingen in te stellen vóór het te laat is ${ }^{\mathbf{1}}$ ).

Van Panhuys stelde op het Congres te Rome nogmaals de reeds op twee vorige Congressen (Londen en Leiden) gedane vraag: waarom de Boschnegers hun "tribal style" hebben kunnen handhaven?

Niemand onder al die geleerden, Congresleden, en naar 't schijnt, de hr. v. Panhuys evenmin, heeft die vraag beantwoord. Dit meen ik ten minste te moeten opmaken uit het op p. 241 gezegde. Toch lijkt mij die vraag geenszins zoo verbijsterend ondoorgrondelijk. Blijkbaar ook niet aan prof. Schrijnen, een der Nederlandsche gedelegeerden bij het Congres te Rome. Althans deze beantwoordde eindelijk de zoo lang gestelde vraag, hetgeen door v. P. ,avec reconnaissance” erkend wordt.

1) Adolf Bastian zeide reeds omstreeks een halve eeuw geleden: „Jede Minute zählt im hinschwinden der Originalitäten." Hoe is het dan nú wel?

West Indische Gids XI 
„Gij hebt hier” — zeide de heer Schrijnen — de „raison anthropologique". Ik vermoed dat hij daarmede den uit Afrika meegebrachten erfelijken aanleg der Boschnegers bedoelde. En dan „l'influence de la tradition". De professor had er, dunkt mij kunnen bijvoegen: het tot nog toe buitengewoon lange isolement der Boschnegers.

Dit alles ligt m. i. zóó voor de hand, is zóó van zelfsprekend, dat ik mij verwonderd afvraag, waarom op drie Congressen een quaero naar het „mysterie” van den ,tribal style" moest gedaan worden.

De hr. v. P. eindigt met den wensch, dat een volgend International Amerikanisten Congres te Paramaribo moge plaats hebben, in 1932, 1936, 1940, of later.

Ik hoop het ook, maar ik denk daarbij onwillekeurig aan het Japansche spreekwoord: „Wanneer men plannen maakt voor het volgend jaar, dan lacht de duivel".

Tunis, Nov. '29

H. TEN KATE 